\title{
Artisanal fisherwomen/shellfish gatherers: analyzing the impact of upper limb functioning and disability on health-related quality of life
}

\author{
Pescadoras artesanais/marisqueiras: \\ análise do impacto da funcionalidade e incapacidade de membros \\ superiores sobre a qualidade de vida relacionada com a saúde
}

\author{
Juliana dos Santos Müller ${ }^{1}$ \\ Ila Rocha Falcão ${ }^{2}$ \\ Maria Carolina Barreto Moreira Couto ${ }^{2}$ \\ Wendel da Silva Viana ${ }^{2}$ \\ Ivone Batista Alves ${ }^{2}$ \\ Denise Nunes Viola ${ }^{3}$ \\ Courtney Georgette Woods ${ }^{4}$ \\ Rita de Cássia Franco Rêgo ${ }^{2}$
}

\footnotetext{
${ }^{1}$ Departamento de

Tecnologia em Saúde e

Biologia, Instituto Federal

de Educação, Ciência

e Tecnologia da Bahia.

R. Emídio dos Santos,

Barbalho. 40301-015

Salvador BA Brasil.

muller.juliana@

yahoo.com.br

${ }^{2}$ Programa de Pós-

Graduação em Saúde,

Ambiente e Trabalho,

Departamento de Medicina

Preventiva, Faculdade de

Medicina, Universidade

Federal da Bahia (UFBA).

Salvador BA Brasil.

${ }^{3}$ Departamento de

Estatística, Instituto

de Matemática, UFBA

Salvador BA Brasil.

${ }^{4}$ Department of

Environmental Sciences and

Engineering, University of

North Carolina. Chapel Hill

NC EUA.
}

\begin{abstract}
The aim is to analyze upper limb functioning and disability, and its association with health-related quality of life among artisanal fisherwomen from Bahia, Brazil. Cross-sectional epidemiological study was conducted with a sample of 209 fisherwomen. Structured questionnaires were used for socio-demographic and comorbidity information, as well as the instruments Disabilities of the Arm, Shoulder and Hand (DASH) and Short-Form Healthy Survey (SF36) respectively, to evaluate the upper limbs and health-related quality of life. The results demonstrated that the presence of musculoskeletal disorders in the upper limbs directly affects the values of the DASH instrument and the SF-36v01 questionnaire scores, while also generating a negative correlation between the DASH and SF-36v01. The varying functioning abilities, pain and social aspects negatively affect upper limb function, and the daily activities and work of fisherwomen. The presence of chronic disease and the absence of intervention and rehabilitation for these professionals, that could produces, in a long-term, cases of disability.

Key words Upper limb functioning and disability, Health-related quality of life, Artisanal fisherwomen/shellfish gatherers, DASH, SF-36
\end{abstract}

Resumo O objetivo foi analisar a incapacidade e a funcionalidade de membros superiores e verificar sua associação com a qualidade de vida relacionada com a saúde de pescadoras artesanais da Bahia, Brasil. Estudo epidemiológico, de corte transversal, envolvendo uma amostra de 209 pescadoras artesanais. Foram utilizados questionários estruturados para informações sociodemográficas e comorbidades e os instrumentos Disabilities of the Arm, Shoulder and Hand (DASH) e Medical Outcomes Study 36-Item Short-Form Healthy Survey (SF-36), para, respectivamente, avaliação dos membros superiores e qualidade de vida relacionada com a saúde. Os resultados encontrados demonstram que a presença de distúrbios musculoesqueléticos (DME) em membros superiores afeta diretamente os valores do instrumento DASH e os escores do SF-36v01, bem como a correlação negativa encontrada entre o DASH e os domínios do SF-36v01. As variáveis capacidade funcional, dor e aspectos sociais afetam negativamente a funcionalidade de membros superiores e as atividades do cotidiano e do trabalho de pescadoras artesanais. A presença de doença crônica e a ausência de intervenção e reabilitação desses profissionais geram, a longo prazo, casos de incapacidade.

Palavras-chave Funcionalidade e incapacidade de membros superiores, Qualidade de vida relacionada com a saúde, Pescadores artesanais/marisqueiras, DASH, SF-36 


\section{Introduction}

Human functioning and disability are a dynamic interaction between health conditions (diseases, trauma, injuries and disorders) and contextual factors (including environmental and personal factors $)^{1}$. According to the World Health Organization ${ }^{2}$, functioning refers to all bodily functions, activities and participation, while disability includes impairments and limitations of activity, and/or restrictions in social participation ${ }^{3}$. Based on these assumptions, it should be noted that the lifestyle and labor activity of a population is directly linked to maintaining functioning and human disability.

The artisanal fisherwomen/shellfish gatherers that are the focus of this study, primarily sustain their families through fishing and shellfish gathering, and good physical condition is fundamental in carrying out these activities due to the style and manner in which the work is performed. According to data from the International Labour Organization (ILO), there are 2 million artisanal fishers in Latin America and the Caribbean, where fishing is more than a job, but a way of life ${ }^{4}$.

In Brazil, according to Ministry of Fisheries and Aquaculture (MPA), there is an estimated one million artisanal fishers, and given Brazil's geographic characteristics, fishers are found along the entire coastline of the country $y^{5}$. In the northeast region, there is fishing and shellfish gathering in "Baía de Todos os Santos", considered the second largest geographical accident of its kind in Brazil, the first being São Marco bay in Maranhão.

Todos os Santos Bay is located in the state of Bahia, and it is estimated that close to 11,850 people practice fishing as a main productive activity, representing $33.8 \%$ of the total of those dedicated to fishing in the entire State of Bahia, a sector that is also excluded from the formal labor market ${ }^{7}$. According to Pena et al. (2011):

"The work of shellfish gatherers at the beach sand and in the mangroves is of an itinerant nature where they maintain their upper body bent over for long periods of times.".

Generally, fishermen works continue to work even in the face of bodily pain, ailments (including musculoskeletal disorders, MSDs) and illness ${ }^{8}$. This could be related to the physical burden of work, as well as the accumulation of housework, thus making the daily lives of these women exhausting and highly dependent on their overall state of health'.
It has become extremely necessary to evaluate the health status of this important group of workers, as the labor activity involved in shellfish gathering is notorious for causing muscle overload in the neck, shoulders, back, upper limbs and lower back, aside from the rhythmic excess centered on the wrist in repetitive activities that compromise health ${ }^{8}$.

Given this premise, it is known that the increasing prevalence of chronic diseases combined with the increasing number of workers that develop long-term dysfunction processes, creates a new demand for health services, as well as a challenge in the identification and professional referrals for these individuals. According to the Ministry of Health ${ }^{10}$, the high prevalence of musculoskeletal disorders is because of changes in the workplace and companies, regardless of the individuals and their physical and psychosocial limitations. Fishing is an occupation that involves ergonomic, physical, chemical and biological risks ${ }^{8}$.

The verification of functioning has become the central factor in assessing and determining conduits, including in patients with chronic medical conditions ${ }^{11}$. Disability generates losses in the individual's functioning, and to analyze the damage, there are generic and specific instruments that are recommended as part of the assessment to measure the psychosocial consequences, the impact of the disease on the individual's routine and dysfunction in the affected limb ${ }^{12}$.

The objective of this article is to analyze the disability and functioning of the upper limbs and examine its association with the health-related quality of life of artisanal fisherwomen from the municipality of Saubara in the state of Bahia.

\section{Materials and methods}

A cross-sectional epidemiological study was conducted with a sample of the population of artisanal fisherwomen/shellfish gatherers from Saubara in the state of Bahia.

Saubara is located in the interior, in the Bahian Recôncavo region, close to the mouth of the Paraguaçu river and is about $94 \mathrm{~km}$ from Salvador by road, and less than $20 \mathrm{~km}$ away by river, with an area of $163 \mathrm{~km}^{2}$ and a rainforest biome ${ }^{13}$. The municipality has three districts (Cabuçu, Bom Jesus dos Pobres and Araripe) and according to the 2010 census, has approximately 11,201 residents ${ }^{14}$, of which $48.9 \%$ are men and $51.1 \%$ are women. The economically active population 
(EAP) is made up of 5,196 people ${ }^{14}$, and artisanal fishing is one of the main economic activities practiced by residents ${ }^{14}$. Artisanal fishers registered with the Saubara Association of Seafood Workers correspond with (11\%) of the EAP.

To calculate the sample, $50 \%$ prevalence and $5 \%$ error was used on the population total $(\mathrm{N})$ of 426 artisanal fisherwomen/shellfish gatherers registered in the municipal Association of Seafood workers, resulting in a minimum sample of 203 individuals. The estimate of the margin of error was between $3 \%$ and $10 \%$, constituting the final sample of 209 participants, 3\% more than the minimum of losses. The sampling was random, simple and without replacement, where each individual was drawn using a random number chart.

Data was collected between April 10 and May 10 of 2013. The interviewers had a minimum of a high school education and their training involved ethical, theoretical and methodological research aspects. The following inclusion criteria was defined for the research participants: female, 18 years of age or older and at least one year of practicing the activity.

The artisanal fisherwomen/shellfish gatherers selected were invited by their association to fill out a questionnaire about health, and were also informed about the broader research objectives that involved the suspected diagnosis of musculoskeletal disorders. Afterwards, all of them were referred to the Occupational Health Services clinic (SESAO) at the Professor Edgard Santos University Hospital (HUPES) for specialized exams. The fisherwomen/shellfish gatherers that did not participate in the study but had some kind of musculoskeletal complaint were also referred to those services.

The total number of people registered with the Saubara Association of Seafood workers during the period of study (April and May of 2013) was 568 individuals, of which 426 (75\%) were females and $142(25 \%)$ were males. The great majority of female artisanal fishers/shellfish gatherers are registered in associations. Since only those registered with associations have a right to access the social benefits the federal government currently grants to artisanal fishers, there is an interest among this poor population to register in order to guarantee their right to those benefits. Therefore, the 426 artisanal fisherwomen/shellfish gatherers is an approximation of the total number of workers in that sector in the municipality, and represents close to $7.4 \%$ of the women residents in Saubara, considering the data from the last census the IBGE carried out in the municipality.

The selected shellfish gatherers for the sample were given three questionnaires. The structured questionnaire had the following items: identification; sociodemographic aspects; work information; current and previous occupational history; duration of time as a shellfish gatherer; daily hours of work; habits like smoking, alcohol consumption, medication use and physical activity; comorbidities; housework; musculoskeletal symptoms; physical and psychosocial demands at work.

The second instrument applied was the Disabilities of the Arm, Shoulder and Hand (DASH), a questionnaire that specifically measures the disability and symptoms of individuals with musculoskeletal disorders in the upper limbs. It is composed of 30 questions related to the health of the individual a week before collection, and has eighteen components: pain, weakness, stiffness, tingling, daily activities, housekeeping, shopping, recreational activities, self-care, dressing, eating, sexual activity, sleep, family care, work, socialization and self-image, plus an optional module for athletes and musicians, and another for workers ${ }^{15}$.

The Brazilian version of Disabilities, Arm, Shoulder and Hand (DASH) showed good validity and reliability, and its use is indicated in specialized services that monitor patients with musculoskeletal diseases. Its use has become interesting, as it contains the physical, social and psychological components proposed by the International Classification of Functioning, Disability and Health (ICF) ${ }^{16}$.

The instrument demonstrated excellent precision for measuring disability in a large group of disorders of the upper limbs, where, regardless of the condition or of its location, the evaluation of the upper limbs was conducted as a functional unit. The analysis of this instrument is shown on a numerical scale of 100-0, and the largest raw scores indicate greater impairment in disability ${ }^{17}$.

The other instrument used in this study was the health-related quality of life questionnaire (SF-36v01), a generic instrument that assesses the general health of individuals. It is composed of 36 questions and produces a profile of eight domains in functioning health and well-being: physical functioning, physical role limitations, bodily pain, general health perceptions, vitality, social functioning, emotional role limitations and mental health. It also includes a comparative question between the health conditions at the 
time of application and a year before. The final score ranges from 0 to 100 , zero corresponding to a worse overall health status and 100 to the best health status. Each domain is analyzed separately so that the real problems related to general health can be identified ${ }^{18}$. According to Ware Jr. ${ }^{19}$, there have been 4,000 publications documenting the use of SF-36.

\section{Ethical Aspects}

This research was submitted and approved by the Committee on Research Ethics in Human Beings (CEP) at the Faculdade de Medicina da Bahia (Parecer 356.261), in accordance with the standards of resolution no. 466 from the National Health Council, December 2012. After the authorization from CEP/UFBA, a request to use the SF-36v01 instrument was submitted to the organization that created this questionnaire. Those that were invited and agreed to participate in the study signed two-way informed consent terms, ensuring the confidentiality of information, their voluntary and anonymous participation, the absence of any compensation for participation in the study, and the availability of researchers to clarify anything about the project before, during and after the study period. Researchers and / or the coordinator of the project carried out instrument application.

\section{Statistical Analysis}

This began with descriptive analysis for each domain from both questionnaires, as well as the calculation of specific scores. For the SF-36v01 instrument, software provided by the creator organization of the instrument was used, of which the calculated scores ranged from 0 to 100 , representing the worst and best quality of life respectively.

To calculate scores from the DASH instrument, the five point Likert scale was used, in which the total score ranges from 100 (severe impairment) to 0 (no impairment). Note that the score of this module can only be calculated if 27 answers from the 30 questions are received. Each question answered has a maximum value of 5 .

The total DASH score was calculated by the sum of the score for each item, decreasing the value of 30 and dividing the result by 1.2. This transformation is made to allow comparison of scores with those of other 0-100 scales, according to the guidelines set by the creator agency. A high score (100) indicates severe dysfunction, and a low score (0) no dysfunction ${ }^{20,21}$. The process described for the dysfunction / symptoms score is also used to calculate the four items from the optional modules. To calculate the score, the four questions of each item must be answered. The optional module score is calculated separately and obtained by the sum of the marked score for each question, reducing the value of 4 and dividing the result by $0.16^{20,21}$. Then the central tendency (mean, median) and dispersion (standard deviation) measures were calculated for each SF-36v01 domain and the total DASH score, as well as the correlation between the domain values of the two instruments. A negative binomial regression model was also performed, as described below.

\section{Dependent Variable}

The response variable was the DASH instrument score that represents the evaluation of the upper limb functioning and symptoms as a functional unit. This value represents the disability and functioning of the upper limbs.

\section{Independent Variables}

The independent variables include all domains of the SF-36v01 questionnaire, sociodemographic information and self-reported chronic diseases. The MSD variable was the only one among the chronic diseases for which research was done with validated instruments, in accordance with previous studies from the Research Group on Health, Environment and Sustainability of Artisanal Fisheries Workers.

For the MSD variable, a record of pain or discomfort in each region in the last twelve months was considered, with a minimum duration of one week or a minimum monthly frequency, not caused by acute injury. Symptoms had to be related to at least one of the following: degree of severity $\geq 3$ on a scale of 0 to 5 (no discomfort to unbearable pain); seeking medical attention because of the problem; absence from work (official or otherwise); change of work because of health restrictions $s^{22,23}$. To calculate MSD, the presence of MSD in at least one of 12 anatomical areas was considered.

\section{Regression Model}

Data was analyzed from a negative binomial regression model according to the characteristics of the sample and the instruments used, 
with support from the free statistical package $\mathrm{R}$ 3.1.3. A negative binomial regression model is used when the outcome under consideration is a count, and the assumption of the Poisson model where the mean is equal to the variance is not respected, often because of the greater dispersion of data. In this article, the variance is greater than the mean.

The pre-selection of the independent variables, for input on both initial multiple linear regression models, was based on the univariate linear regression, considering a $\mathrm{p}$-value less than 0.25 in the Wald test for coefficient significance. The biological plausibility of the associations was also considered for entry into the initial models. Thus, the variables selected: physical functioning, bodily pain, social functioning, mental health, MSD in the shoulder, wrist / hand and overall MSD (all body segments).

In the third model, these variables were selected: functioning, bodily pain, social functioning, MSD in the shoulder, wrist / hand with p-value less than 0.17 . The final model was derived from the variables with p-values less than 0.05 , leaving, in the final model, physical functioning, bodily pain and social functioning, as shown in Table 1.

\section{Results}

A total of 209 artisanal fisherwomen / shellfish gatherers participated in this study. The entire sample is composed of women between the ages of 30 and 44 (78\%), black or brown (96.2\%), with a maximum elementary school education (77\%), and predominantly married (64.6\%). The presence of chronic diseases showed musculoskeletal disorders, especially in the upper limbs (as shown in Table 1), correlating with the instrument used in this study.

Table 2 shows the descriptive analysis of the domain scores from the SF-36v01 and DASH instruments (general and optional). The mean DASH (dysfunction and symptoms) found for this population was 30.8 with a standard deviation (SD) of 21.0, and the optional DASH was 29.0 with a standard deviation (SD) of 27.7; For the SF-36v01 instrument, the mean score ranged from 47.3 to 66.4 .

A DASH instrument comparison between its general part (dysfunction and symptoms) and its optional part (leisure and business) there were no significant differences found in the medians.

Table 3 shows the mean scores of the DASH instrument in relation to the presence of mus-
Table 1. Socioeconomic distribution and chronic diseases among artisanal fisherwomen/shellfish gatherers from Saubara-Bahia, 2013.

\begin{tabular}{|c|c|c|c|}
\hline & Variables & $\begin{array}{c}\mathrm{N} \\
(209)\end{array}$ & $\%$ \\
\hline \multicolumn{4}{|l|}{ Age } \\
\hline $20-29$ & & 47 & 22 \\
\hline $30-44$ & & 94 & 45 \\
\hline $45-64$ & & 68 & 33 \\
\hline Race & & & \\
\hline
\end{tabular}

Black

Brown

White

Marital status

Single

Married/Unmarried couple/Living

together

Separated/Widow

Schooling

Up to 4 years

5 to 8 years

9 to 11 years

Chronic Diseases

Musculoskeletal Disorders*

Neck

Yes

No

Shoulder

Yes

No

Elbow

Yes

No

Forearm

Yes

No

Wrist/Hand

Yes

No

Upper Back

Yes

No

Overall MSD*

Yes

No

Diabetes $^{* *}$

Yes

No

Hypertension ${ }^{\star \star}$

Yes

No

Arthritis**

Yes

No
$125 \quad 60$

$76 \quad 36$

$8 \quad 3,8$

$56 \quad 27$

$135 \quad 65$

$18 \quad 8,6$

$48 \quad 23$

$94 \quad 45$

$67 \quad 32$

32 shoulder and distal upper liming (on forearm, wrist/heck MSD analysis according to this classification is considered by some author ${ }^{24,25}$. $* *$ The comorbidities (diabetes, hypertension and arthritis) found were collected from what was selfreported. 
culoskeletal disorders in the upper limbs: neck (35.5), shoulder (37.9), elbow (43.4), forearm (38.6), wrist / hand (37.5) and upper back (35.9). It demonstrated that the presence of MSD's in the upper limbs increases the mean values of the DASH instrument for all segments.

A correlation between DASH scores and the SF-36v01 values from domains grouped into eight categories, representing the negative correlation in which the increase of the DASH value (severe dysfunction) diminishes the health-relat-

Table 2. Descriptive analysis of the DASH and SF-36v01 instruments from artisanal fisherwomen / shellfish gatherers from Saubara-Bahia, 2013.

\begin{tabular}{lcl}
\hline \multicolumn{1}{c}{ Instruments } & Mean & SD \\
\hline DASH & 30,8 & 21,0 \\
Optional DASH & 29,0 & 27,7 \\
SF-36v01 & & \\
$\quad$ Physical Functioning & 65,7 & 24,9 \\
$\quad$ Physical Role limitations & 47,3 & 40,8 \\
Bodily Pain & 50,4 & 25,4 \\
General Health Perceptions & 51,2 & 21,8 \\
Vitality & 54,5 & 22,9 \\
Social Functioning & 66,4 & 30,5 \\
Emotional Role Limitations & 62,4 & 42,9 \\
Mental Health & 64,8 & 23,5 \\
\hline
\end{tabular}

ed quality of life, except in the physical and emotional functioning domains.

The final model of the negative binomial regression is shown in Table 4, where the variables physical functioning, bodily pain, social functioning and MSD in the wrist (selected variables) adversely affect the functioning of upper limbs. The $\mathrm{p}$ values are highly significant in physical functioning capacity $(<0.000)$, bodily pain $(<$ 0.000 ), and lower statistical significance for the variable social functioning (0.011).

\section{Discussion}

This study aimed to assess upper limb functioning and correlate it with the HRQOL of artisanal fisherwomen / shellfish gatherers from Saubara-Bahia by applying the DASH and SF-36v01 instruments. It should be noted that systematically reviewed studies in the national literature that addressed this issue were not found, particularly with this group of workers. International studies discuss the interference of chronic disease on quality of life, however they carried out research using quantitative tools.

Since this is an original study, and various diseases were detected in the sample, it is of utmost importance to analyze the failure of the functioning point of view in the artisanal fish-

Table 3. Mean and standard deviation of the DASH instrument scores according to MSD distribution in artisanal fisherwomen / shellfish gatherers from Saubara-Bahia, 2013.

\begin{tabular}{lcccc}
\hline Musculoskeletal Disorder & Mean & SD & n & $\%$ \\
\hline Neck & 35,5 & 23,2 & 132,0 & 63,3 \\
Yes & 22,6 & 17,0 & 77,0 & 36,7 \\
No & & & & \\
Shoulder & 37,9 & 22,5 & 111,0 & 53,1 \\
Yes & 22,7 & 18,3 & 98,0 & 46,9 \\
No & & & & 19,6 \\
Elbow & 43,4 & 26,3 & 41,0 & 80,4 \\
Yes & 27,7 & 19,7 & 168,0 & 37,3 \\
No & & & 62,7 \\
Forearm & 38,6 & 24,8 & 78,0 & \\
Yes & 26,1 & 18,6 & 131,0 & 63,6 \\
No & & & 39,4 \\
Wrist/Hand & 37,5 & 22,8 & 133,0 & 61,2 \\
Yes & 18,0 & 14,1 & 76,0 & 38,8 \\
No & & & \\
Upper back & 35,9 & 22,0 & 128,0 & \\
Yes & 22,6 & 17,5 & 81,0 & \\
No & & & \\
\hline
\end{tabular}


The correlation between the SF-36v01 and DASH findings demonstrated the presence of difficulty in carrying out daily tasks (moderate dysfunction), directly implying the HRQOL of the artisanal fisherwomen/shellfish gatherers studied. The mean score found with the DASH application (dysfunction and symptoms) was 30.8 , confirming other studies ${ }^{29}$ that recognized a difficulty in physical, social, psychological and symptomatic dimensions when applying this instrument. On the other hand, there was no statistical difference in the mean values of the two DASH instrument modules. However, this comparison of the overall DASH module scores for artisanal fisherwomen / shellfish gatherers is weak because there are no normative reference studies of the Brazilian population, it is only applicable in orthopedic and surgical diseases.

In a study conducted in Turkey with patients with rheumatoid arthritis, a high negative correlation between the DASH mean values and the physical health components from the SF-36 were found. With regard to artisanal fishers from Saubara-Bahia, the presence of chronic diseases as a result of work activity was proven, with the physical functioning and bodily pain domains (from the SF-36v01 instrument) being statistically significant ( $\mathrm{p}$-value $<0.000$ ) in relation to the dysfunction of the upper limbs.

Bouts in the shoulder segment generated pain and reduced joint mobility and consequently, adversely affected the functioning skills, job activities, and the quality of life of those people ${ }^{30}$. In addition, disorders of this joint represent a critical socio-economic problem in the case of artisanal fishers, for health maintenance is necessary to perform the work that generates family subsistence.

For Moraes et al..$^{31}$, upper limb disability of workers who expose this joint complex to a large amount of repetitive movement, and position the upper limbs in the shoulder abduction, is associated mainly with muscle fatigue, work organization factors, cancellation of the labor regulation mechanism with a subsequent overload (decrease or lack of range), and psychosocial factors that cause tension and stress.
In a study by Pena et al. ${ }^{8}$, the need for a causal link for the emergence of repetitive stress injuries (RSI) in the upper limbs among artisanal fishers From Maré Island-Bahia was emphasized. The daily labor activities develop into a dorsiflexion posture with an extended arm doing abduction and flexion movements, along with the hand holding the instrument. To find the shellfish, an average of ten upper limb movements are necessary per unit collected, with one hand firmly holding and bending a spoon, knife or small spade, and the other hand free to store the collected shellfish in a container.

Investigating the presence of musculoskeletal disorders in artisanal fishers is considered recent, and the Research Group on Health, Environment and Sustainability of Artisanal Fisheries linked to the Federal University of Bahia (UFBA) discussed this reality. It is known that occupational factors only began to be examined in the 1970's, and in light of adequate epidemiological methods, work-related MSD's have become an object of research in international scientific literature ${ }^{32}$.

This study demonstrates that the presence of MSD's in the upper limbs increases the DASH instrument mean scores, confirming thus that chronic pathological involvement increases the upper limb disability (moderate impairment) of artisanal fisherwomen. This thus sheds light upon a serious condition because, due to the informality of this work activity, the guarantee of pension rights and healthcare necessary under these conditions become too complex. It is important to note, however, that solely identifying a clinical condition does not predict with accuracy the care needed, job performance, social benefits or social integration. Thus, the work of artisanal fisherwomen / shellfish gatherers should be observed more closely, especially by public authorities.

For Moliner et al..$^{33}$, the quality of life deteriorates to the extent that people experience chronic disability caused by MSD's or work accidents. In the study by Roux et al. ${ }^{34}$ using the SF-36, bodily pain was the most affected area, making the individuals too disabled to carry out daily activities, and contributing to the reduction of their HRQOL. This finding confirms those of the present study because the physical functioning and bodily pain domains were the statistically significant variables for the disability outcome.

The discussion of disability and loss of function of the upper limbs of artisanal fishers / shellfish gatherers demonstrated in this study, confirms a deficit in the promotion, prevention 
and maintenance of health conditions of this profession. It is clear that the presence of chronic disease and the absence of interventions that make possible the rehabilitation of these professionals generate long-term, permanent disability cases that cripple the livelihoods of traditional communities.

In contrast to this cruel reality, section $\mathrm{V}$ of article 1 of the National Policy on Sustainable Development of Traditional Peoples and Communities $^{35}$, determines sustainable development as promoting improvement in the quality of life within current generations of traditional peoples and communities, while ensuring the same opportunities for future generations and respecting their ways of life and traditions. However, integration of all the public policy spheres is still needed to achieve this goal.

Subsequently, this confirms the need for a specific and effective policy for artisanal fishing, as the current exclusion of this practice from the occupational healthcare system within the Unified Health System (SUS) has been highlighted. For Pena and Martins $s^{36}$ there is a need to understand the significance of workload and the risk of illness, among others, taking into account the historical social context of these conditions.

\section{Conclusion}

This study was fundamental in confirming the upper limb impairment of artisanal fisherwomen/shellfish gatherers as a functional unit, and demonstrated that the physical functioning and bodily pain domains interfere in the functioning and activities of daily life and work.

It is clear that the disability outcome of upper limbs investigated in this study have a negative impact on the HRQOL of artisanal fisherwomen. The impact worsens the health status and as a result, degrades health and increases the exhaustive workload.

The upper limb disorders represent an important socioeconomic problem and, in the case of artisanal fisherwomen, a very critical one, as health maintenance is necessary to perform the work that generates family subsistence. This discussion should be broadened in order to improve the health care for this professional category, where specific decisions and measures are geared towards addressing their chronic medical conditions. 


\section{Collaborations}

JS Müller, IR Falcão and RCF Rêgo conceptualized the study. JS Müller, IR Falcão, RCF Rêgo, MCBM Couto, WS Viana, IB Alves and DN Viola contributed to the study design, data collection and data processing and statistical analysis. JS Müller, IR Falcão and RCF Rêgo contributed to the literature review. JS Müller, IR Falcão, RCF Rêgo and CG Woods wrote the article. All authors reviewed the manuscript and approved the final version.

\section{Acknowledgments}

The authors wish to thank the Foundation for Research Support in Bahia (FAPESB) for financing the study; the Conselho Nacional de Desenvolvimento Científico $(\mathrm{CNPq})$ for the grant for RCF Rêgo as a visiting scholar during the year 2015 and 2016 at the North Carolina University at Chapel Hill in USA, and finally the local communities for agreeing to participate in this study.

\section{References}

1. Sampaio RF, Luz MT. Funcionalidade e incapacidade humana: explorando o escopo da classificação internacional da Organização Mundial da Saúde. Cad Saude Publica [periódico na Internet]. 2009 Mar. [acessado 2014 Fev 12] 25(3):475-483.Disponível em: http:// www.scielo.br/scielo.php?script=sci_arttext\&pi$\mathrm{d}=\mathrm{S} 0102-311 \mathrm{X} 2009000300002 \& \operatorname{lng}=\mathrm{en} \& \mathrm{nrm}=$ iso

2. Organização Mundial da Saúde (OMS). CIF: Classificação Internacional de Funcionalidade, Incapacidade e Saúde. São Paulo: Edusp; 2003.

3. Fontes AP, Fernandes AA, Botelho MA. Funcionalidade e incapacidade: aspectos conceptuais, estruturais e de aplicação da Classificação Internacional de Funcionalidade, Incapacidade e Saúde (CIF). Revista Portuguesa de Saúde Pública [periódico na Internet]. 2010 [acessado 2014 Jan 23]; 28(2):171-178. Disponível em: http:// www.scielo.gpeari.mctes.pt/scielo.php?script=sci_arttext\&pid=S0870-90252010000200008\&lng=pt\&nrm = iso

4. Organização Internacional do Trabalho (OIT). Convenção 188: referente ao trabalho na pesca. 2007. [acessado 2013 jan 5]. Disponível em: http://www.oitbrasil. org.br/content/referente-ao-trabalho-na-pesca

5. Brasil. Ministério da Pesca e Aquicultura (MPA). Pesca artesanal. [internet]. 2012 [acessado 2014 Nov 11]. Disponível em: http://www.mpa.gov.br/\#pesca/pesca -artesanal

6. Bandeira FPSF, organizador. Estudo etnoecológico sobre a percepção das populações ribeirinhas dos riscos e impactos ambientais na Baía de Todos-os-Santos (BTS). Salvador: IMA, Secretaria do Meio Ambiente e Recursos Hídricos, EGBA; 2009.

7. Bandeira FPSF, Brito RRC. Comunidades pesqueiras na Baía de Todos os Santos: aspectos históricos e etnoecológicos. In: Caroso C, Tavares F, Pereira C, editores. Bahia de Todos os Santos: aspectos humanos. Salvador: Edufba; 2011.p. 291-326.

8. Pena GL, Freitas MCS, Cardim A. Trabalho artesanal, cadências infernais e lesões por esforços repetitivos: estudo de caso em uma comunidade de mariscadeiras na Ilha de Maré, Bahia. Cien Saude Colet 2011;16(8):33833392.

9. Müller JS, Falcão I, Couto MCB, Viana WS; Alves IB, Viola D, Woods CG, Rêgo RCF. Health-Related Quality of Life among Artisanal Fisherwomen/Shellfish Gatherers: Lower than the General Population. Int J Environ Res Public Health 2016; 13(5):466.

10. Brasil. Ministério da Saúde (MS). Dor relacionada ao trabalho: lesões por esforços repetitivos (LER):distúrbios osteomusculares relacionados ao trabalho (Dort). Brasília: Editora do Ministério da Saúde; 2012.

11. Brockow T, Cieza A, Kuhlow H, Sigl T, Franke T, Harder $\mathrm{M}$, Stucki G. Identifying the concepts contained in outcome measures of clinical trials on musculokeletal disorders and chronic widespread pain using the Internacional Classification of Functioning, Disability and Health as a reference. J Rehabil Med 2004; 44(Supl.):30-36.

12. Ferreira EAG. Postura e controle postural: desenvolvimento e aplicação de método quantitativo de avaliação postural [tese]. São Paulo: Universidade de São Paulo; 2005. 
13. Instituto Brasileiro de Geografia e Estatística (IBGE). Dados básicos. [internet]. 2007 [acessado 2013 Jan 10]. Disponível em: <http://www.ibge.gov.br/cidadesat/painel $/$ painel.php?codmun $=292975 \#>$.

14. Instituto Brasileiro de Geografia e Estatística (IBGE). Estimativas de população para $1^{\circ}$ de julho de 2011. [internet]. 2011 [acessado 2013 Jan 10]. Disponível em: http://www.ibge.gov.br/home/estatistica/populacao/ estimativa2011/tab_Municipios_TCU.pdf

15. Orfale AG. Tradução e validação do Disabilities of the Arm, Shoulder and Hand (DASH) para a lingua portuguesa [tese]. São Paulo: Universidade Federal de São Paulo; 2003.

16. Drumond AS. Exploração do Disabilities Arm, Shoulder and Hand (DASH) através da Classificação Internacional de Funcionalidade, Incapacidade e Saúde (CIF) e da análise Rasch. [dissertação]. Belo Horizonte: Universidade Federal de Minas Gerais; 2006.

17. Gummesson C, Ward MM, Atroshi I. The shortened disabilities of the arm, shoulder and hand questionnaire (QuickDASH):validity and reliability based on responses within the full-length DASH. BMC Musculoskeletal Disorders 2006; 7(44):1-7.

18. Ciconelli RM. Tradução para o português e validação do questionário genérico de avaliação de qualidade de vida Medical Outcomes Study 36-Item Short-Form Health Survey (SF-36) [tese]. São Paulo: Universidade Estadual de São Paulo; 1997.

19. Ware Junior JE. SF-36 Health Survey Update. [internet].2007 [acessado 2014 Mar 15]. Disponível em: http://www.sf-36.org

20. Orfale AG, Araújo PMP, Ferraz MB, Natour J. Translation into Brazilian Portuguese, cultural adaptation and evaluation of the reliability of the Disabilities of the Arm, Shoulder and Hand Questionnaire. Brazilian Journal Medical and Biological Research 2005; 38(2):293-302.

21. Cheng HMS, Sampaio RF, Mancini MC, Fonseca ST, Cotta RMM. Disabilities of the arm, shoulder and hand (DASH):factor analysis of the version adapted to Portuguese/Brazil. Disability and Rehabilitation 2008; 30(25):1901-1909.

22. Kuorinka I, Forcier L. Work related musculoskeletal disorders (WMSDs): a reference book for prevention. London: Taylor \& Francis; 1995.

23. Fernandes RCP, Assunção AA, Silvany Neto AM, Carvalho FM. Musculoskeletal disorders among workers in plastic manufacturing plants. Rev. bras. epidemiol. 2010;13(1):11-20.

24. Wang P-C, Rempel DM, Harrison RJ, Chan, J, Ritz BR. Work, organisational and personal factors associated with upper body musculoskeletal disorders among sewing machine operators. Occupational and environmental medicine 2007; 64(12):806-813.

25. Andersen JH, Haahr JP, Frost P. Risk Factors for More Severe Regional Musculoskeletal Symptoms. Arthritis Rheum 2007; 56(4):1355-1364.

26. Falcão IR, Couto MCBM, Lima VMC, Pena PGL, Andrade LL, Müller JS, Alves IB, Viana WS, Rêgo RCF. Prevalence of neck and upper limb musculoskeletal disorders in artisan fisherwomen/shellfish gatherers in Saubara, Bahia, Brazil. Cien Saude Colet 2015; 20(8):2469-2480.

27. Couto MCBM. Prevalência e fatores associados à lombalgia em pescadoras artesanais/marisqueiras de Sauba$r a-B A$ [dissertação]. Salvador: Universidade Federal da Bahia; 2014.
28. Walsh IAP, Corral S, Franco RN, Canetti EEF, Alem MER, Coury HJCG. Capacidade para o trabalho em indivíduos com lesões músculo-esqueléticas crônicas. Rev Saude Publica [periódico na Internet]. 2004 Fev. [acessado 2014 Jan 21]; 38(2):149-56.Disponível em: http://www.scielo.br/scielo.php?script=sci_arttext\&pi$\mathrm{d}=$ S0034-89102004000200001\&lng=en\&nrm=iso.

29. Papp MR, Souza RC, Lima SMPF, Matsumoto MH, Chamliam TR, Santos JBG. Comparação entre DASH e SF-36 do cotovelo traumatizado reabilitado na terapia ocupacional. Acta Ortopedica Brasileira [periódico na Internet]. 2011 Jun. [acessado 2015 Jan 3]; 19(6):356-361. Disponível em: http://www. scielo.br/scielo.php?script=sci_arttext\&pid $=$ S1413 $-78522011000600007 \& \operatorname{lng}=$ en\&nrm=iso.

30. Mousavi SJ, Parnianpour M, Abedi M, Askary-Ashtiani A, Karimi A, Khorsandi A, Mehdian H. Cultural adaptation and validation of the Persian version of the Disabilities of the Arm, Shoulder and Hand (DASH) outcome measure. Clin Rehabil 2008; 22(8):749-757.

31. Moraes GFS, Gonçalves FM, Silva JD, Soares NS. Correlação entre posicionamento escapular, análise postural funcional e grau de incapacidade dos membros superiores (DASH Brasil) em médicos ultrassonografistas. Radiologia Brasileira. [periódico na Internet].2009 [acessado 2015 Fev 20]; 42 (1):[ cerca de 6 p.]. Disponível em: http://www.scielo.br/scielo.php?script=sci_arttext\&pid=S0100-39842009000100008\&lng=en\&nrm=iso.

32. Bernard BP, editor. Musculoskeletal disorders and workplace factors: a critical review of epidemiologic evidence for work related musculoskeletal disorders of the neck, upper extremity, and low back. 1997. [Internet].1997 [acessado 2015 Fev 20]. Disponível em: http:// www. cdc.gov/niosh/docs/97-141/\#disclaimer.

33. Moliner CE, Durand MJ, Desrosiers J, Coutu MF. Subjective quality of life according to work status following interdisciplinary work rehabilitation consequent to musculoskeletal disability. J Occup Rehabil 2007; 17(4):667-682.

34. Roux CH, Guillemin F, Boini S, Longuetaud F, Arnault N, Hercberg S, Briançon S. Impact of musculoskeletal disorders on quality of life: an inception cohort study. Annals of the Rheumatic Diseases 2005; 64(4):606-611.

35. Brasil. Ministério do Meio Ambiente (MMA). Institui a política nacional de desenvolvimento sustentável dos povos e comunidades tradicionais. Decreto no 6.040, de 07 de fevereiro de 2007. Diário Oficial da União 2007; 8 fev.

36. Pena GL, Martins VLA. Sofrimento negligenciado: doenças do trabalho em marisqueiras e pescadores artesanais. Salvador: EDUFBA; 2014.

Artigo apresentado em 17/05/2016

Aprovado em 25/11/2016

Versão final apresentada em 27/11/2016 